\title{
Ukrajinske družbene spremembe v romanu Dvanajst krogov Jurija Andruhoviča
}

Janja Vollmaier Lubej

Institut für Slawistik, Philologisch-Kulturwissenschaftliche Fakultät, Universität Wien janja.v@windowslive.com

Prispevek predstavi družbene spremembe v Ukrajini po njeni odcepitvi od Sovjetske zveze in v času nove, kapitalistične dobe, kot so predstavljene v romanu Dvanajst krogov ukrajinskega pisatelja Jurija Andruhoviča. Prispevek se ukvarja z ekonomsko podobo postsovjetske Ukrajine in predstavi nekaj ključnih posledic, ki jih lahko opazimo v omenjenem romanu. To so delavske migracije, zapuščeni otroci, prostitucija, odvisnost od alkohola.

Ključne besede: Dvanajst krogov, delavske migracije, zapuščeni otroci, prostitucija, odvisnost od alkohola, kapitalizem

Social Changes in Ukraine in Yuri Andrukhovych's Novel Twelve Rings

The article presents social changes in Ukraine after its secession from the Soviet Union and also in a new, capitalist, era as they are presented in a novel by the Ukrainian writer Yuri Andrukhovych, Twelve Rings. The present contribution examines the economic aspect of post-Soviet Ukraine and presents some of main conesquences they had and which are described in the aforementioned novel. They are economic migration, abandoned children, prostitution, alcoholism.

Key words: Twelve Rings, economic migration, children left behind, prostitution, alcoholic dependence, capitalism 


\section{Postsovjetska Ukrajina}

Ko je leta 1991 razpadla Sovjetska zveza in si je Ukrajina kot njena nekdanja sovjetska socialistična republika namesto totalitaristične stalinistične-leninistične ideologije izbrala pot $\mathrm{v}$ demokratično državo, je bila deležna številnih političnih, gospodarskih, kulturnih in družbenih sprememb. Vzpostavitev oziroma gradnja nove družbene skupnosti je bila zapleten proces. Razpad Sovjetske zveze je potekal po mirni poti, a oblikovanje nove, samostojne države še zdaleč ni bil enostaven. Ob osamosvojitvi Ukrajine so se ustvarila velika pričakovanja za prihodnost v neodvisni državi, ki naj bi postala bogata demokracija s prostim trgom ter polnopravna članica evropske in evroatlantske skupnosti, a se ta pričakovanja (še) niso izpolnila (Sutela 2012). Najsodobnejša Ukrajina beleži približevanja Evropski uniji in tudi njena oddaljevanja (Janukovičeva zavrnitev podpisa pridružitvenega sporazuma med Evropsko unijo in Ukrajino, kar je povzročilo evromajdan) in še danes, sedemindvajset let po osamosvojitvi, ne moremo pisati o konkretnih pomikih.

Ukrajina se je po letu 1991 soočala $\mathrm{z}$ veliko gospodarsko in ekonomsko krizo, ki je bila tudi posledica industrializacije, nekonkurenčnosti (Sutela 2012), država, ki je bila nekdaj vodilna v kmetijski panogi, se srečuje z neizkoriščenimi kmetijskimi površinami, premogovniki, ki so nekoč ustvarjali dobiček, so v novi dobi prinašali izgubo. Mnogi vzroke za slabo finančno stanje države po osamosvojitvi vidijo tudi v prerivanju politikov za oblast oziroma v zamenjavi elit (Kutsyuruba 2011, Sutela 2012, Rjabčuk 2014, Die Ukraine - Land mit zwei Gesichtern 2014). Hkrati se je v državi pojavilo in obdržalo veliko oligarhov, ki so izkoristili čas privatizacije, zaradi sumljivega bogastva pa nadzorujejo gospodarstvo in imajo izstopajočo vlogo tudi v politiki (Unabhängige Ukraine 2015). Rezultat tega je viden še danes, ko lahko opazujemo ogromen prepad med revnimi in bogatimi, vsedovoljenost in kršenje zakona na eni ter kratenje svobode na drugi strani. Zaradi politične nestabilnosti $\mathrm{v}$ nanovo ustanovljeni državi ni bilo mogoče vzpostaviti funkcionalnih administrativnih institucij (Sutela 2012) in s tem, ko je vsakršno spoštovanje zakona izpuhtelo, ukrajinsko gospodarsko okolje ni bilo spodbudno za tekmovanje, vlaganje, razvoj (prav tam). Prav tako se je država soočala $\mathrm{z}$ velikim koruptivnim tveganjem in sivo ekonomijo, ki sta še danes eni večjih ukrajinskih težav. Glede na različne vire siva ekonomija danes v Ukrajini dosega od 20 do 50 \% (Bochi, Povoroznyk 2014, 1). Glede na ocene številnih mednarodnih strokovnjakov odtok denarja kot posledica korupcije presega 10 bilijonov dolarjev letno (Bochi, Povoroznyk 
2014, 2). Denar se izgublja tudi zaradi izplačevanja plač v kuvertah, pri čemer naj bi vrednost takega plačila letno zavzemala 200 bilijonov UAH (prav tam). Dalje, indeks ekonomije svobode ocenjuje, da ima Ukrajina ene slabših pogojev za ekonomski razvoj med državami Evropske unije in nekdanjimi državami Sovjetske zveze (Bochi, Povoroznyk 2014, 4). Glede na indeks zaznave korupcije pa se je država v letu 2013 znašla na 144. mestu od 177. držav (prav tam). Nekateri avtorji korupcijo opisujejo tudi kot endemično (Düvell, Lapšina 2015, Sutela 2012).

Hkrati je bila Ukrajina neuspešna v izvozu in vodenju domačega gospodarstva (Sutela 2012). Nekateri proces ukrajinskega gospodarstva vidijo kot "pošasten divjezahodni kapitalizem, ki je peščici omogočil nenormalno bogatenje, večino pa je pahnil v še globljo revščino" (Die Ukraine - Land mit zwei Gesichtern 2014). Ukrajina je po osamosvojitvi postala svetovna periferija, $v$ kateri so razlike med bogatimi in revnimi še večje in globlje. $\mathrm{V}$ nemški reviji Der Spiegel iz leta 1994 lahko beremo, da je "preteklemu sovjetskemu modelu gospodarstva [...] sledil še absurdnejši, ki nima niti načrta niti trga, temveč mu vlada zakon džungle« (Die Ukraine - Land mit zwei Gesichtern 2014).

Čeprav je Ukrajina prvih sedem let novega tisočletja doživljala gospodarsko rast, se je ta zaradi globalne gospodarske krize leto kasneje ustavila (Unabhängige Ukraine 2015). Pretresljivo je, da je Ukrajina danes druga najbolj revna evropska država, sploh upoštevaje, da je bila sosednja Poljska, ki je danes gospodarsko uspešna, leta 1990 na primerljivem ekonomskem izhodišču: po uradnih podatkih naj bi BDP prve znašal 1.569 USD na prebivalca, druge 1.693 USD, leta 2012 pa je ukrajinski BDP 3.866, medtem ko je poljski 12.707 USD (Fisher 2014).

Hkrati se je postsovjetski posameznik v novi družbi težko znašel. Na nek način je hotel zabrisati vsakršne sovjetske sledi preteklosti in kolektivnega spomina, po drugi strani pa novih oblik pri vzpostavljanju samostojne države ni mogel ali hotel zlahka sprejeti. Vesna V. Godina v svoji monografiji Zablode postsocializma (2014) na podlagi ugotovitev antropologov sklene, da posamezniki v novih družbah ohranjajo delovanja, standarde oz. tisto, kar izvira iz preteklosti, s tem pa novim postsocialističnim institucijam onemogočajo delovanje. Prav tako pogosto ovirajo in onemogočajo postsocialistične spremembe $(2014,111)$. V postsocialističnih družbah nove institucije in prakse niso zaživele in $\mathrm{v}$ družbah obstajajo kot tujek (Hann 2007, 277-278, povz. po Godina 2014, 111). Večina učiteljev iz mesta Černivci je leta 2005 odgovorila, da so spremembe v socialni sferi slabše, 
ljudje pa so se bili zaradi izgube nekdanjega načina življenja prisiljeni prilagoditi novim resničnostim. Precej učiteljev je potrdilo, da so v novi državi medčloveški odnosi postali bolj brezčutni in hladni (Kutsyuruba 2011).

Ukrajina pa se, kakor vse ostale vzhodne države, ni izognila uveljavitvi kapitalizma. Po mnenju antropologov (npr. Hann, Kideckel, gl. Godina $2014,127)$ je $\mathrm{v}$ postsocialističnih družbah šlo za nov tip kapitalizma, imenovanega neokapitalizem, za katerega je značilna "predelava temeljnih kapitalističnih principov na nove, še bolj neegalitarne načine kot zahodni model« (Kiedeckel 2007, 115-116, povz. po Godina 2014, 127). Vzpostavile so se svetovne periferije, ki so rezultat odvisnosti Vzhodne Evrope od svetovnega kapitala, pri čemer je nepravično bogatenje na eni in vse večja revščina na drugi neizpodbitno dejstvo in velik vsesplošen globalizacijski problem, ki se mu tudi Ukrajina ni izognila.

\section{Posledice novih družbeno-ekonomskih resničnosti}

Posledice izpostavljenih težav, s katerimi se srečuje postsovjetska Ukrajina, so delavske in ekonomske migracije ter upad ukrajinskega prebivalstva, zapuščeni otroci, porast alkoholizma in feminizacija revščine, ki se kaže v prostituciji.

Ukrajina se sooča $\mathrm{z}$ upadom pričakovane življenjske dobe, eden od pomembnih vzrokov za to pa je tudi alkohol. Uradni podatki sicer kažejo, da je poraba alkohola na prebivalca $v$ litrih čistega alkohola malo nad evropskim povprečjem in da upada (14,3 za obdobje 2003-2005, 13,9 za obdobje 2008-2010, medtem ko je evropsko povprečje 11,9 oziroma 10,9) (WHO 2014), a poudariti je treba, da podatki niso realni. Strokovnjaki namreč opozarjajo na zavajajoče podatke in da stopnja odvisnih od alkohola pravzaprav narašča (Samokhvalov et al. 2009).

Ukrajina se od osamosvojitve sooča $\mathrm{z}$ množičnim izseljevanjem in je država $z$ eno največjih diaspor na svetu, ki predstavlja 5-6 milijonov ljudi. Ukrajinsko prebivalstvo se je v obdobju 1991-2015 zmanjšalo za devet milijonov (iz 52 na 42,9 milijonov) (Düvell, Lapšina 2015). Sodobna Ukrajina se sooča s številnimi delavskimi migracijami, opazen je porast migracij na Poljsko, zlasti zaradi jezikovnih in kulturnih podobnosti pa tudi zaradi preprostih, brezplačnih birokratskih postopkov (Jaroszewicz 2015, 5). Veliko Ukrajincev dela tudi v drugih evropskih državah, npr. na Češkem, v Italiji, Španiji, na Nizozemskem idr., v glavnem so to slabo plačana dela v neurejenih pogojih. Po podatkih iz leta 2012 je 3,4 \% ukrajinske populacije delavskih migrantov, $25 \%$ pa jih v tujini dela ilegalno (Malinkovska 2006). 
Posledice delavskih migracij so zapuščeni otroci, ki so jih primorani vzgajati stari starši oz. drugi sorodniki ali prijatelji. Jasno je, da odsotnost enega ali obeh staršev povzroča velike travme (Janovič 2015) in hude življenjske preizkušnje. V Ukrajini prva ločitev otroka in starša traja od dveh do petih let. Žalostno je še, da delavske migracije postajajo vse bolj trajne in takšna je tudi vez med vse bolj dejansko in simbolno oddaljenimi otroki ter njihovimi starši (Malinovska 2006).

Nekatere države nekdanje Sovjetske zveze, med njimi je tudi Ukrajina, so postale osrednje države glede prostitucije (Hughes 2003). V seksualni industriji so najbolj popularne ženske iz Ukrajine in Rusije. Med letoma 1991 in 1998 se je v prostitucijo na zahod podalo 500.ooo Ukrajink (Hughes 2003, 11). Leta 1998 je kriminalistična preiskava v Nemčiji ugotovila, da je $87,5 \%$ prostitutk v Nemčiji iz Vzhodne Evrope, od tega 14 \% iz Ukrajine (Hughes 2003, 10). Poleg osnovnih vzrokov (brezposelnost, nizke plače) so vzroki za porast prostitucije tudi $\mathrm{v}$ njeni toleranci $\mathrm{v}$ ukrajinski resničnosti, $\mathrm{v}$ feminizaciji revščine in normalizaciji te problematike. Danes individualna prostitucija v Ukrajini ni kaznivo dejanje. Tragično je, da so žrtve nedelujoče države in njenega sistema tudi otroci, ki so kot ženske prisiljeni v trgovino $\mathrm{z}$ belim blagom.

\section{Odslikava ukrajinske postsovjetske resničnosti v literarnih delih Jurija Andruhoviča}

Jurij Andruhovič (1960) je vidnejši ukrajinski postmodernistični pisatelj, pesnik in esejist, ki je za svoje literarno delo prejel več uglednih domačih in tujih nagrad. V svojih romanih, ki so prevedeni $v$ številne jezike in s katerimi je bil deležen največ kritiške naklonjenosti, piše o posttotalitarni, postsovjetski Ukrajini in položaju posameznika in/ali skupnosti v njej. Andruhovičeva velika ustvarjalna tema je "vprašanje posameznikove in/ali kolektivne identitete $\mathrm{v}$ tranzicijskem in postsovjetskem obdobju « (Vollmaier Lubej 2016, 212) in v svojih romanih želi preseči imperialistično preteklost (prav tam). Njegove literarne osebe določa travmatizirana preteklost, ki ji v sedanjosti niso zmožne ubežati. Andruhovič v svojih romanih, Rekreacije (1992), Moskoviada (1993), Perverzija (1996) in Dvanajst krogov (2003), tematizira imperialistično preteklost, življenje v imperiju in posledice za posameznika in skupnost. Avtor predstavlja usodo posameznika, ki je v poosamosvojitvenem času še vedno ukleščen $\mathrm{v}$ ostaline totalitarnosti in zato ni zmožen nanovo zaživeti. Njegove pripovedi se torej naslanjajo na travmo, na brezizhodnost tako posameznika kot skupnosti. 
V svojem literarnem delu Jurij Andruhovič posebno mesto namenja (Ne) Evropi in položaju Ukrajine $\mathrm{v}$ njej in poudarja zapostavljenost Ukrajine $\mathrm{v}$ Evropi. Avtorjev zadnji roman Dvanajst krogov (2003) se tem vprašanjem, tj. podobi Ukrajine v Evropi, ostalinam totalitarne preteklosti, približa preko tujca, Avstrijca Josepha Zumbrunnena, ki je v svojih opažanjih in pisanjih karseda objektiven, prav tako pa roman tematizira življenje v dobi kapitalizma in potrošništva ter upošteva njene posledice.

\section{Roman Dvanajst krogov}

Ko je leta 2003 izšel roman Dvanajst krogov, ki ga je mogoče brati kot kritiko ukrajinske družbe, so nekateri zaradi slednjega pisatelju očitali zaničevalno upodabljanje Ukrajine in celo trdili, da je plačanec Zahoda. Toda Andruhovič je pisatelj, ki je v svojih literarnih besedilih kritičen do ukrajinske situacije in ji nastavlja objektivno ogledalo, problematike pa niti v esejih niti v romanih ne podaja enostransko, temveč jo osvetljuje s širšekulturnega, širšedružbenega vidika.

$\mathrm{V}$ romanu večperspektivno predstavlja ukrajinsko resničnost ter $\mathrm{z}$ zlom napolnjen pretekli in sodobni čas. Roman Dvanajst krogov je nastal $\mathrm{v}$ času, ko se je Ukrajina navidezno že oddaljila od sovjetske podrejenosti in se začela politično ter kulturno približevati evropski skupnosti oz. njeni ideji. Toda še vedno je zaznati ostaline vseprisotne totalitarnosti ter njenega prepleta $\mathrm{z}$ novo dobo kapitalizma in potrošništva. Videti je, da se krogotok zgodovine zla nadaljuje tudi v novi, neodvisni ukrajinski stvarnosti. Roman predstavlja posameznika in skupnost $\mathrm{v}$ tem modificiranem času in prostoru ter prikazuje posledice, ki smo jim priča danes. To je družba brez vrednot, skupnost, ki se množično izseljuje v sosednje države zaradi boljšega življenja, družba, ki ne spoštuje Romov, družba, ki ji ni mar za umetnost. Namesto naštetega se vzpostavljajo plehkost, hitro, nepošteno bogatenje, izigravanje sistema, laganje idr. Jurij Andruhovič je postmodernistični ukrajinski pisatelj, ki je v literarni prostor vstopil kot pesnik. V romanu Dvanajst krogov se pojavljajo tri osrednje osebe: ukrajinski pisatelj-pijanec Artur Pepa, njegova žena, prevajalka, germanistka Roma Voronič kot usodna ženska in odgovorna mati ter avstrijski fotograf Karl Joseph Zumbrunnen, ki ukrajinščine ne zna, svojo jezikovno pomanjkljivost pa nadomešča s fotografiranjem in s kritičnim očesom dobesedno in simbolno slika ukrajinsko trpko resničnost počasnih vlakov, vizumskih dovoljenj, carinikov, izklopljene elektrike in zlasti žalostno usodo države, ki je sicer imela potencial, a ga ni znala ali zmogla izkoristiti. Med Arturjem, 
Romo in Karlom Josephom je vzpostavljen nevaren ljubezenski trikotnik, ki je za slednjega usoden. Vsi trije se skupaj z ostalimi gosti pripeljejo v Karpate v Krčmo na Mesecu, da bi tam obeležili spomin na pozabljenega ukrajinskega pesnika iz tridesetih let prejšnjega stoletja Bogdana Igorja Antoniča, ki mu pisatelj v šestem poglavju nameni literarizirano fiktivno biografijo, v kateri se poleg njegovih pesmi pojavijo pričevanja, spomini, polresnice, zavajanja, zlasti pa odnos tedanje družbene elite do pesnikovega dela in življenja. Poleg središčnih oseb so v romanu prisotni še Romina hči Kolomeja, profesor, poznavalec Antoničeve poezije, koketnici in glavni junakinji reklamnega videa za alkoholni zvarek Lilija in Marlena, režiser Volšebnik ter tajkun in oligarh Varcabič. V pripovedi ni veliko dogajanja, to pa za Andruhovičev romaneskni opus ni nobena novost. Žanrsko je roman družbenokritični, ljubezenski, kriminalni in detektivski. Jurij Andruhovič $\mathrm{v}$ svojih romanih ustvarja mračno, brezizhodno, groteskno vzdušje, ki se v zgodovinskem času in prostoru nevarno ponavlja v modificiranih oblikah. Tak je tudi roman Dvanajst krogov, ki že v naslovu namiguje na simboliko kroga kot večno ponavljanje in vračanje na začetek.

\section{Analiza}

Analiza zajema predpostavko, da roman Dvanajst krogov večperspektivno odslikava ukrajinske družbene spremembe, ki se kažejo v posttotalitarni in postsovjetski resničnosti. Analiza ob tem želi predstaviti tudi podobo kapitalistične in potrošniške ukrajinske resničnosti, kot je podana v izbranem romanu.

\section{Družbene spremembe v Dvanajstih krogih}

Roman je postavljen $\mathrm{v}$ devetdeseta leta prejšnjega stoletja, $\mathrm{v}$ čas, ko Ukrajina postane neodvisna in samostojna država. Ekonomski strokovnjaki z zahoda so tedaj ocenjevali, da se lahko razvije v stabilno državo s konkurenčnim gospodarstvom. Poleg tega je ukrajinsko gospodarstvo med nekdanjimi državami Sovjetske zveze predstavljalo izjemen gospodarski in industrijski potencial. Po osamosvojitvi se pospešuje propad industrije in kmetijstva, sesuje se bančni sistem, kar vodi v izgube delovnih mest in posledično ekonomske migracije.

Delavski migrantki v romanu sta Lilija in Marlena, ki predstavljata še eno ukrajinsko stvarnost, tj. popredmetenje žensk: Liliji so na Češkem obljubili delovno mesto plesalke, Marlena občasno na Poljskem pleše v 
baru, medtem ko njuna sosošolka Leska $\mathrm{v}$ Benetkah sedi v plačljivem stranišču in čaka na prostovoljne prispevke ljudi. Tako se skozi koketnici in neumni ženski kaže feminizacija revščine in na prvi pogled morda svobodna izbira prostitucije. V romanu snemata reklamo za Varcabičev balzam s pomanjkljivo obleko in sta predstavljeni kot poželjiva objekta. Njun preprost pogovor priča o tem, da ne govorita o svojih čustvih, doživljanjih, preteklih spominih, temveč govorita o tem, kje lahko kaj zaslužita. Podani sta kot sodobni potrošnici, ki morata skrbeti za svoje telo, da bi ugajali in se karseda približali lepotnemu idealu. Lilija in Marlena se razlikujeta samo po svoji zunanjosti in sta tisti sodobnici, ki so ju ustvarili televizija, revije in sovjetski način življenja. Sta punci, ki o ničemer ne razmišljata, premišljujeta, skozi dialoškost pa normalizirata prostitucijo in popredmetenje žensk v sodobni dobi. Njun zaslužek je nizek in jima ne omogoča dostojnega življenja, sta žrtvi sodobnega seksualnega suženjstva. Roman tako prikazuje tudi spremenjen odnos do telesa, telesnosti, poudareni sta detabuizacija spolnosti in svobodno odločanje pri izbiri spolnega življenja. Roma prevara svojega moža Arturja, s čimer krši t. i. tradicionalne vrednote in rahlja t. i. tradicionalni zakon. Pri Romi, Marleni in Liliji se kaže tudi vpliv globalnega trga na dojemanje lepote, sledenje trendom in sprejemanje lastnega telesa kot predmet poželjivosti in komercializacije.

Percepcija delavskih migracij kot narobe razumljeno upanje na boljši jutri je $\mathrm{v}$ romanu podana skozi oči tujca, ki tudi sicer $\mathrm{z}$ največjo ostrino popisuje ukrajinsko resničnost $\mathrm{v}$ svojih pismih avstrijskim prijateljem. Avstrijec Karl Joseph Zumbrunnen, ki ima razmerje z Romo, slednjo prepričuje, naj zapusti domovino in se z njim odpravi kamor koli drugam, s takšnimi prošnjami in obljubami pa je podan kot zahodni bogat sebičnež, ki je na neki točki pozabil, da ima Roma hčer. Zgodi se preobrat, saj ga ljubimka ravno zaradi tega dejstva zavrne. Noče postati transnacionalna mati, ki bi na daljavo skrbela za svojega otroka, se mu oddaljila in ga dala v oskrbo drugim ljudem.

Da se samostojna Ukrajina še ni povsem oddaljila od nekdanjega režima, pričajo Zumbrunnenova pisma, $v$ katerih piše o nepojasnjenih nesrečah, samomorih, izginotjih politikov, novinarjev ipd. Vzpostavlja se nova represija in totalitarnost, nesvoboda izražanja, vse to pa opazi tujec in ne domačini sami. Karl Joseph Zumbrunnen se v Ukrajino vrača večkrat, prvič je tja prišel na začetku devetdesetih, ko je bila povsem nova, samostojna državna tvorba. Svoja opažanja monološko in deskriptivno opisuje v 
pismih avstrijskim prijateljem. O tem, da je samostojna država zapravila svojo priložnost, piše leta 1994:

Ta dežela je imela čudovito priložnost za spremembno, iz stanja trajne popačenosti in oligofreničnega brezupa skoraj bliskovito poskočiti vsaj do stanja normalnosti. Toda izkazalo se je, da število tistih, ki znotraj nje same tega ne želijo in nasploh ne želijo njenega obstoja kot takšnega, bistveno presega vse dopustne meje. (Anduhovič 2006, 11-12)

Videti je, da izmed vseh literarnih oseb le Zumbrunnen kot tujec zmore resneje in bolj poglobljeno analizirati ter pisati o ukrajinski stvarnosti. Preko njegovih pisem izvemo, da Ukrajino pestijo številne težave pri vzpostavitvi nove države, ki se sooča z ostalinami preteklosti. Tako na enem mestu poudari, da je življenje $\mathrm{v}$ nanovo ustanovljeni državi za nekatere nevarno, izpostavi prisluškovanja, nepojasnjene umore, porast kriminala, zlasti pa zlate čase za črni trg s strelnim orožjem. Sedanji totalitarizem ironično imenuje plazeči se, pojavlja se torej še naprej v neodvisni državi, le v drugačni, modificirani obliki. Opaža, da je ljudi strah živeti v takšni državi, neodzivnost organov pregona pa zapiše $\mathrm{z}$ aforizmom: »Policijska država je tam, kjer je policija $v$ enaki meri vsemogočna do poštenih državljanov in nemočna pred zločinci« (Andruhovič 2016, 20).

Dvanajst krogov predstavlja tudi spremenjeno vlogo umetnosti/umetnika v družbi ter spremenjene odnose med posamezniki, pri čemer obe iztočnici stremita $\mathrm{k}$ hitremu in nerazumevajočemu izpraznjevanju bistva. $\mathrm{V}$ romanu je tako prisotna spremenjena podoba umetnosti v sodobni, postmoderni družbi, ki je $\mathrm{v}$ širšem kontekstu prepredena $\mathrm{z}$ radikalno sekularizacijo, diferenciacijo, ideološko fragmentacijo (Zupan Sosič 2011, 150). Artur Pepa je kvazipisatelj, ki ves čas premišljuje, kaj bi napisal, a svoje ideje le stežka ubesedi. Deležen je tudi cenzure, ko je s svojo knjigo hotel prevrednotiti literarni kanon, s sežigom knjige pa je obsojen na javni linč. Rad bi napisal bestseller, želi si ugajati, s tem pa se že približuje polju trivialnosti in podrejenosti, ki ju narekuje sodobna dobičkonosna družbena resničnost. Artur je predstavljen skozi svoja neumna dejanja (zlasti tedaj, ko se zaradi prevare hoče maščevati ženinemu ljubimcu Zumbrunnenu), določajo pa ga tudi povprečni, prazni dialogi. Ima težave $\mathrm{z}$ alkoholom in zaradi pijančevanja resne zdravstvene probleme s srcem. Še stopnjevan kvaziumetnik v romanu je režiser Volšebnik, ki bere in izbira poneumljajoče scenarije za reklamo, vsi pa namigujejo na spolnost in erotičnost. Zanj je pomemben le družbeni status. $\mathrm{V}$ romanu so poudarjeni manipulativni vzgibi, ki bi omogočili izkrivljanje polpretekle literarne zgodovine, pesmi Igorja 
Bogdana Anotniča, ki je ustvarjal na začetku dvajsetih in tridesetih let prejšnjega stoletja in mu Andruhovič nameni šesto poglavje, njegove pesmi pa so smiselno vpete $\mathrm{v}$ roman, so mestoma predstavljene poenostavljeno, poneumljajoče, vse z razlogom, da bi pesnika popularizirale. Volšebnikova pritlehnost je jasno izražena $\mathrm{v}$ njegovih pogovorih $\mathrm{z}$ ostalimi, kjer je očitno, da ni sposoben spregovoriti brez mašil, prekinitev, njegov govor ni dokončan, besedni zaklad pa je na izredno osiromašen. Umetnost je prodal zaradi komercializacije, sledenja trendom in lastnega dobička. Edino upanje za umetnost je Romina hči Kolja, mladoletno dekle, ki razume pomen Antoničevih dvanajstih krogov pomladi in je prijetna sogovornica.

Videti je, da groteskno izvotljenost stopnjuje svet, v katerem so poudarjeni prazni izrazi, hitro, nekritično zadovoljstvo in odsotnost samoobvladovanja. $\mathrm{V}$ postsovjetski resničnosti vidi spremenjeno vlogo umetnosti tudi ugledni ukrajinski pisatelj Andrej Kurkov, in sicer, da je bilo v samostojni državi mogoče »objavljati vse; toda literatura je izgubila svojo vlogo « (Dović 2008, 15). Na to posredno opozarja tudi roman Dvanajst krogov, hkrati pa izpostavlja cenzuro v navidezni svobodi. Arturju Pepi so namreč zaradi njegovih novih pogledov na književnost sežgali eno od njegovih knjig.

Omenjeno je bilo, da se je v neodvisni Ukrajini vzpostavilo okolje za porast oligarhov, ki nadzorujejo gospodarstvo, politiko idr. V romanu je tajkun in oligarh predstavljen v podobi Varcabiča, lastnika letovišča, v katerem so nastanjene glavne literarne osebe, avtomobilskega odpada in beznice. Predstavljen je kot nadčlovek, ki se nikdar ne pojavi, z literarnimi osebami komunicira posredno in mu je dovoljeno vse, ima pa tudi nepredstavljivo moč v vseh porah družbe.

Velik problem današnje Ukrajine je alkoholizem, posledice katerega niso le posameznikov razpad, uničene družine in širše skupnosti, temveč tudi izginotje številnih ukrajinskih vasi. Mnogo Ukrajincem predstavlja popivanje način življenja. V romanu je podano veseljačenje, utapljanje nezadovoljstva $\mathrm{v}$ alkoholu in literarne osebe nasploh veliko pijejo, zlasti Artur Pepa.

V Dvanajstih krogih se pojavi tudi velikanski avtoodpad, lastnik katerega je že omenjeni oligarh Varcabič, ta literarni prostor pa predstavlja metaforo o končnosti dovčerjašjega sveta in/ali začetku nečesa novega. Tam se v zapuščenem avtu znajdeta Artur Pepa in Roma, ki premišljujeta o prihodnosti njune ljubezni in pomenljivosti prostor-časa, $\mathrm{v}$ katerega sta ujeta. Roman še na več mestih poudarja zanemarjenost, umazanost ukra- 
jinskih rek, potokov, $s$ čimer avtor namiguje na resnično perečo težavo, $s$ katero se država sooča. Pomenljivo je, da je bilo leta 1990 v državnih rekah za 19,7 bilijona kubičnih metrov odplak (Boreyko 1993).

Jurij Andruhovič je tudi avtor več esejističnih zbirk, v katerih izpostavljene teme podaja v luči evropske ignorance do Ukrajine in (ne)približevanja Ukrajine Evropi. V esejih iz zbirke Дезорієнтація на місцевості se poglablja v različne teme, zlasti se večkrat dekriptivno navezuje na zunajliterarne topose, na Ukrajino, Lvov, habsburški prostor z vso svojo jezikovno-kulturno barvitostjo, prav tako pa ga zanima podoba umetnosti, umetnika, pri čemer se večkrat obrača $\mathrm{k}$ pesniku Bogdanu Igorju Antoniču, ki mu v Dvanajstih krogih namenja posebno mesto.

\section{Zaključek}

Roman Dvanajst krogov je časovno postavljen v devetdeseta leta, v ukrajinsko samostojnost in neodvisnost ter podaja življenje $\mathrm{v}$ postsocialistični državi. Videti je, da sta posameznik in širša družbena skupnost kljub navidezni svobodi v nanovo ustanovljeni državi še vedno vpeta v preteklost in tradicijo, zato morebitnih sprememb na bolje ni. Še več, življenje takoj po osamosvojitvi v tej državi ni prijetno in ne omogoča dostojnosti, zato se pojavijo številne negativne posledice za skupnost, mdr. migracije, zapuščeni otroci, porast prostitucije, zasidran problem alkoholizma, prav tako pa se vzpostavljajo modificirane oblike starega sistema, kot jih opaža tujec Karl Joseph Zumbrunnen, pa tudi že soočanje s posledicami kapitalizma. Vsevedni pripovedovalec pred bralca večperspektivno predoči neizbežno žalostno usodo države, ki je imela potencial, a ga ni znala ali zmogla izkoristiti.

\section{Viri in literatura}

Andruhovič, Jurij. 2016. Dvanajst krogov. Ljubljana: Cankarjeva založba. Andruhovič, Jurij.1999. Дезорієнтація на місцевості. Лілея - НВ.

Bochi, Angela; Povoroznyk, Vasyl. 2014. "Shadow economy in Ukraine: causes and solutions «. International Centre for Policy Studies: 1-7. icps.com.ua Boreyko, Volodymyr. 1993. »The environment: Pollution plagues large areas of Ukraine«. The Ukrainian Weekly LXI/6. <Http://www.ukrweekly.com/ old/archive/1993/o69303.shtml>. (Dostop 1. 6. 2016.)

Düvell, F., Lapšina, I. »The EuroMaidan Protests, Corruption, and War in Ukraine: Migration Trends and Ambitions«. $<$ Http://www.migrationpol- 
icy.org/article/euromaidan-protests-corruption-and-war-ukraine-migration-trends-and-ambitions $>$. (Dostop: 1. 6. 2016.)

Fisher, Reinis. 2014. »Ukraine vs Poland by GDP 1990-2012«. <Http://www. reinisfischer.com/ukraine-vs-poland-gdp-1990-2012.>. (Dostop: 1.6. 2016.)

Godina, Vesna V. 2014. »Drugi pogled: uvedba antropološke perspektive«. V Vesna V. Godina, Zablode postsocializma, 100-180. Ljubljana: Beletrina.

Hughes, Donna M., Denisova Tatyana. 2003. Trafficking in Women From Ukraine. U. S. Department of Justice.

Janovič, Liza. 2015: »Children Left Behind: The Impact of Labor Migration in Moldova and Ukraine«. <Http://www.migrationpolicy.org/article/ children-left-behind-impact-labor-migration-moldova-and-ukraine $>$. (Dostop: 1. 6. 2016.)

Jaroszewicz, Marta. 2015. "The migration of Ukrainians in times od crisis«. Centre for Eastern Studies 187: 1-8.

$<$ Http://www.osw.waw.pl/sites/default/files/commentary_187.pdf $>$. (Dostop: 1. 6. 2016.)

Kutsyuruba, Benjamin. 2011. »Education in the Period of Post-Soviet Transition in Ukraine«. Democracy. A journal od ideas: 287-309. Winter Issue 2011.

$<$ Https://www2.gwu.edu/ ieresgwu/assets/docs/demokratizatsiya\%2oarchive/GWASHU_DEMO_19_3/J57410H66R1H7404/J57410H66R1H7404. pdf $>$. (Dostop: 1. 6. 2016.)

Levchuk, Natalia. 2009. "Alcohol and morality in Ukraine«. Rostock: MaxPlanck-Institut für demografische Forshung: 1-24.

<Http://www.demogr.mpg.de/papers/working/wp-2009-017.pdf $>$. (Dostop: 1. 6. 2016.)

Malinovska, Olena. 2006. »Caught Between East and West, Ukraine Struggles with Its Migration Policy«. <Http://www.migrationpolicy.org/article/ caught-between-east-and-west-ukraine-struggles-its-migration-policy>. (Dostop: 1. 6. 2016.)

Portnov, Andrij. 2014. »Postsowjetische Hybridität und "Eurorevolution" in der Ukraine - Essay«. <Http://www.bpb.de/apuz/194814/postsowjetische-hybriditaet-und-eurorevolution? $\mathrm{p}=\mathrm{o}>$. (Dostop: 1. 6. 2016.)

»Die unabhängige Ukraine«. 2015. Bundeszentrale für politische Bildung. $<$ Http://www.bpb.de/izpb/209819/die-unabhaengige-ukraine>. (Dostop: 1. 6. 2016.) 
»Die Ukraine - Land mit zwei Gesichtern«. 2014. <Http://www.mdr.de/damals/ archiv/ukraine194.html>. (Dostop: 1. 6. 2016.)

Samokhvalov, A. V., Pidkorytov, V. S., Linskiy, I. V., Minko, O. I., Minko, O. O., Rehm, J., Popova, S. 2009. "Alcohol use and addiction services in Ukraine«. International Psychiatry 6 (1): 5-7. $<$ Http://www.psychiatry.ua/ eng/engo 49.htm>. (Dostop: 1. 6. 2016.)

Sutela, Pekka. 2012. »The Underachiever: Ukraine's Economy Since 1991«.

$<\mathrm{Http}$ //carnegieendowment.org/2012/03/o8/underachiever-ukraine-s-economy-since-1991-pub-47451>. (Dostop: 1. 6. 2016.)

WHO. Ukraine: Alcohol Comsumption. <Http://www.who.int/substance_ abuse/publications/global_alcohol_report/profiles/ukr.pdf>. (Dostop: 1 . 6. 2016.)

Vollmaier Lubej, Janja. 2016. »V temni noči opotekajoči se pijanec«. V Dvanajst krogov, Jurij Andruhovič, 209-220. Ljubljana: Cankarjeva založba.

Zupan Sosič, Alojzija. 2011. »Trivialnost«. Slavistična revija 59/2: 147-160. 